\title{
Conceptual Development of a National Volcanic Hazard Model for New Zealand
}

\begin{abstract}
Mark Stirling ${ }^{1 *}$, Mark Bebbington ${ }^{2}$, Marco Brenna ${ }^{1}$, Shane Cronin ${ }^{3}$, Annemarie Christophersen ${ }^{4}$, Natalia Deligne ${ }^{4}$, Tony Hurst ${ }^{4}$, Art Jolly ${ }^{4}$, Gill Jolly ${ }^{4}$, Ben Kennedy ${ }^{5}$, Gabor Kereszturi ${ }^{2}$, Jan Lindsay ${ }^{3}$, Vince Neall ${ }^{2}$, Jonathan Procter ${ }^{2}$, David Rhoades ${ }^{4}$, Brad Scott ${ }^{6}$, Phil Shane ${ }^{3}$, Ian Smith ${ }^{3}$, Richard Smith ${ }^{7}$, Ting Wang ${ }^{1}$, James D. L. White ${ }^{1}$, Colin J. N. Wilson ${ }^{8}$ and Tom Wilson ${ }^{5}$
\end{abstract}

\begin{abstract}
${ }^{1}$ Department of Geology, University of Otago, Dunedin, New Zealand, ${ }^{2}$ Institute of Agriculture and Environment, Massey University, Palmerston North, New Zealand, ${ }^{3}$ School of Environment, University of Auckland, Auckland, New Zealand, ${ }^{4}$ GNS Science, Lower Hutt, New Zealand, ${ }^{5}$ Geological Sciences, University of Canterbury, Christchurch, New Zealand, ${ }^{6}$ GNS Science, Wairakei, New Zealand, ${ }^{7}$ Earthquake Commission, Wellington, New Zealand, ${ }^{8}$ School of Geography, Environment and Earth Sciences, Victoria University of Wellington, Wellington, New Zealand
\end{abstract}

OPEN ACCESS

Edited by:

Valerio Acocella,

Roma Tre University, Italy

Reviewed by:

Gordon Woo,

Risk Management Solutions (United Kingdom), United Kingdom

Sebastien Biass,

Hawaii University, United States

${ }^{*}$ Correspondence:

Mark Stirling

mark.stirling@otago.ac.nz

Specialty section:

This article was submitted to Volcanology,

a section of the journal Frontiers in Earth Science

Received: 22 December 2016 Accepted: 06 June 2017

Published: 22 June 2017

Citation:

Stirling M, Bebbington M, Brenna M,

Cronin S, Christophersen A

Deligne N, Hurst $T$, Jolly A, Jolly $G$, Kennedy B, Kereszturi G, Lindsay J,

Neall $V$, Procter $J$, Rhoades $D$, Scott B, Shane P, Smith I, Smith $R$

Wang T, White JDL, Wilson CJN and Wilson T (2017) Conceptual Development of a National Volcanic Hazard Model for New Zealand. Front. Earth Sci. 5:51. doi: 10.3389/feart.2017.00051
We provide a synthesis of a workshop held in February 2016 to define the goals, challenges and next steps for developing a national probabilistic volcanic hazard model for New Zealand. The workshop involved volcanologists, statisticians, and hazards scientists from GNS Science, Massey University, University of Otago, Victoria University of Wellington, University of Auckland, and University of Canterbury. We also outline key activities that will develop the model components, define procedures for periodic update of the model, and effectively articulate the model to end-users and stakeholders. The development of a National Volcanic Hazard Model is a formidable task that will require long-term stability in terms of team effort, collaboration, and resources. Development of the model in stages or editions that are modular will make the process a manageable one that progressively incorporates additional volcanic hazards over time, and additional functionalities (e.g., short-term forecasting). The first edition is likely to be limited to updating and incorporating existing ashfall hazard models, with the other hazards associated with lahar, pyroclastic density currents, lava flow, ballistics, debris avalanche, and gases/aerosols being considered in subsequent updates.

Keywords: volcanic, hazard, New Zealand, probabilistic, ashfall

\section{INTRODUCTION}

Natural hazard models are developed to quantify perils such as volcano, earthquake, landslide, tsunami, and flooding events. The models are designed for application to a wide variety of end-user needs, such as engineering, planning, loss assessment, and emergency responses by civil authorities and agencies (e.g., Petersen et al., 2014). An important class of model is the national hazard model, which provides first-order estimates of the location and expected severity of natural hazards across a country (e.g., Stirling et al., 2012) to serve a multitude of purposes in the engineering, planning, insurance, and emergency management sectors. Not surprisingly, the development of national hazard models have progressed at different rates in different countries, and for different perils (e.g., Stirling et al., 1998; Hurst and Smith, 2010; Dellow et al., 2013). The models typically give estimates of the severity and associated frequency of a hazard at a site, or across a grid of sites 
(e.g., Cornell, 1968). The earliest New Zealand model of this scale was developed for earthquakes, and the four-step process of probabilistic seismic hazard assessment (PSHA) is shown as an example in Figure 1. Prior to the development of the PSHA method, seismic hazard assessments were deterministicallybased, giving estimates of the severity of hazard at a site, with no information on the frequency (e.g., Reiter, 1990). In today's environment probabilistic seismic hazard (PSH) models also provide deterministic (scenario) outputs, which usually define major earthquakes that are expected to impact a site (Figure 1; Reiter, 1990).

The New Zealand's National Seismic Hazard Model (NSHM) is the country's most mature national probabilistic hazard model, with four major iterations completed over the last 30 years (Smith and Berryman, 1986; Stirling et al., 1998, 2002, 2012). The National Tsunami Hazard Model (NTHM) has received two iterations in the last decade (Berryman, 2005; Power, 2013).

Quantifying probabilistic volcanic hazard follows four steps equivalent to those shown in Figure 1 and as originally described by Stirling and Wilson (2002): Step 1, identifying volcanic sources around a site; Step 2, defining eruption volume-frequency distributions; Step 3, expressing the dependence of hazard at the site on eruption volume and distance from the eruption; and Step 4, integrating Steps 1-3 for over all sources to estimate the probability of exceedance of a given severity of hazard during a given time period. Similar steps, preceded by an initial screening, form the basis of volcanic hazard assessment for nuclear installations (IAEA, 2012, 2016).

A logical early approach to developing a National Volcanic Hazard Model (NVHM) is to learn from existing volcanic hazard model developments at scales ranging from global to site-specific. There is no formal NVHM that comprehensively addresses all of New Zealand's active volcanoes (Figure 2). A national volcanic ashfall hazard model has been developed for the country (Hurst and Smith, 2010; Figure 3), but it does not address the volcanic hazards of lahars, pyroclastic density currents, ballistic clasts, debris avalanches, gases/aerosols, and lava flows. Landslide hazard is quantified at a national scale, however, for rainfall induced landslides (Dellow et al., 2013). The maturity of the New Zealand NSHM relative to the other models can be attributed to the initial development of probabilistic hazard methods in the domain of earthquakes (Cornell, 1968), and to institutional priorities being strongly focused on seismic hazard until the early 2000s. The NSHM developments have been greatly facilitated by the quality and quantity of earthquake data accumulated over historical time. Much fundamental work is now required to

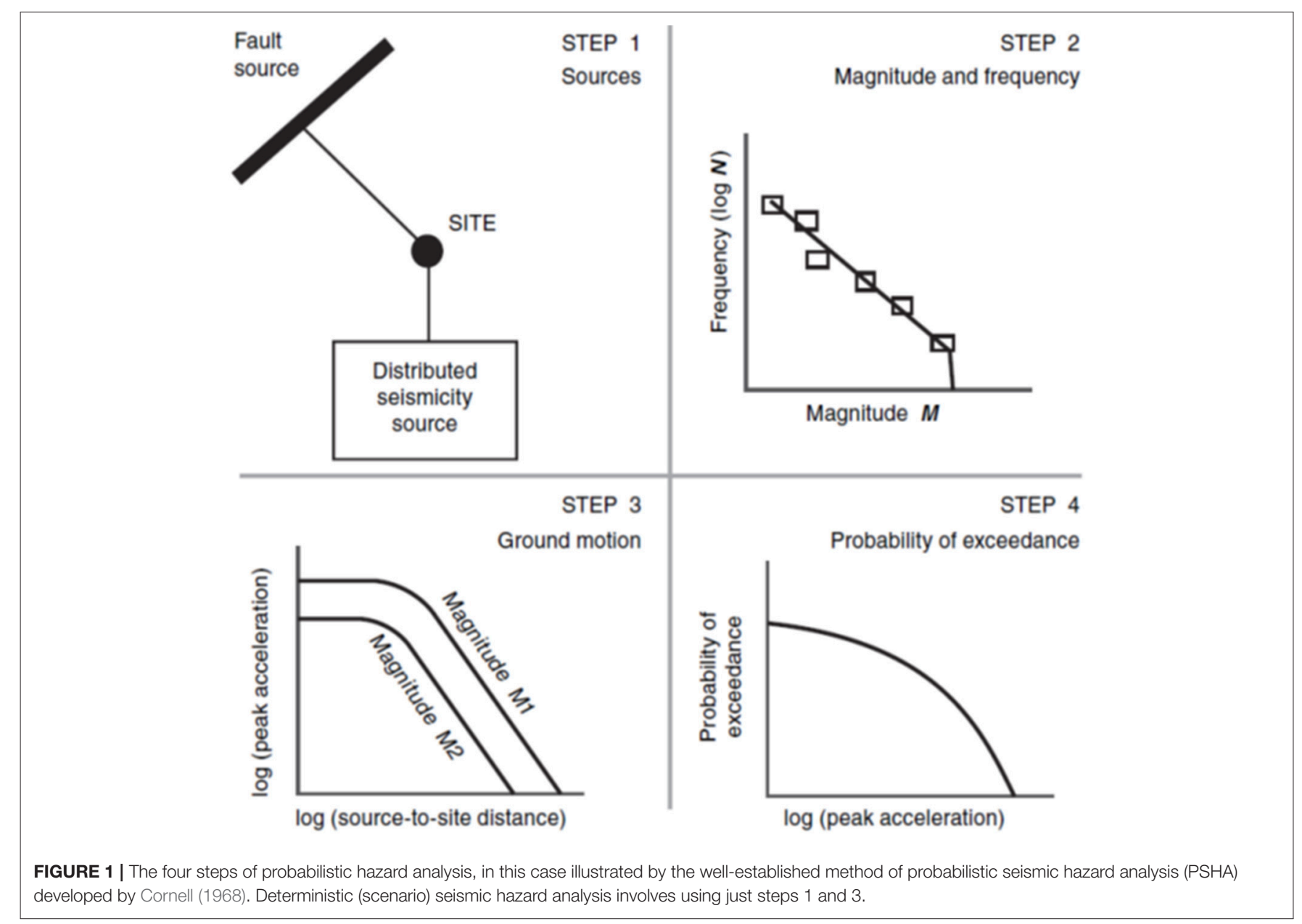




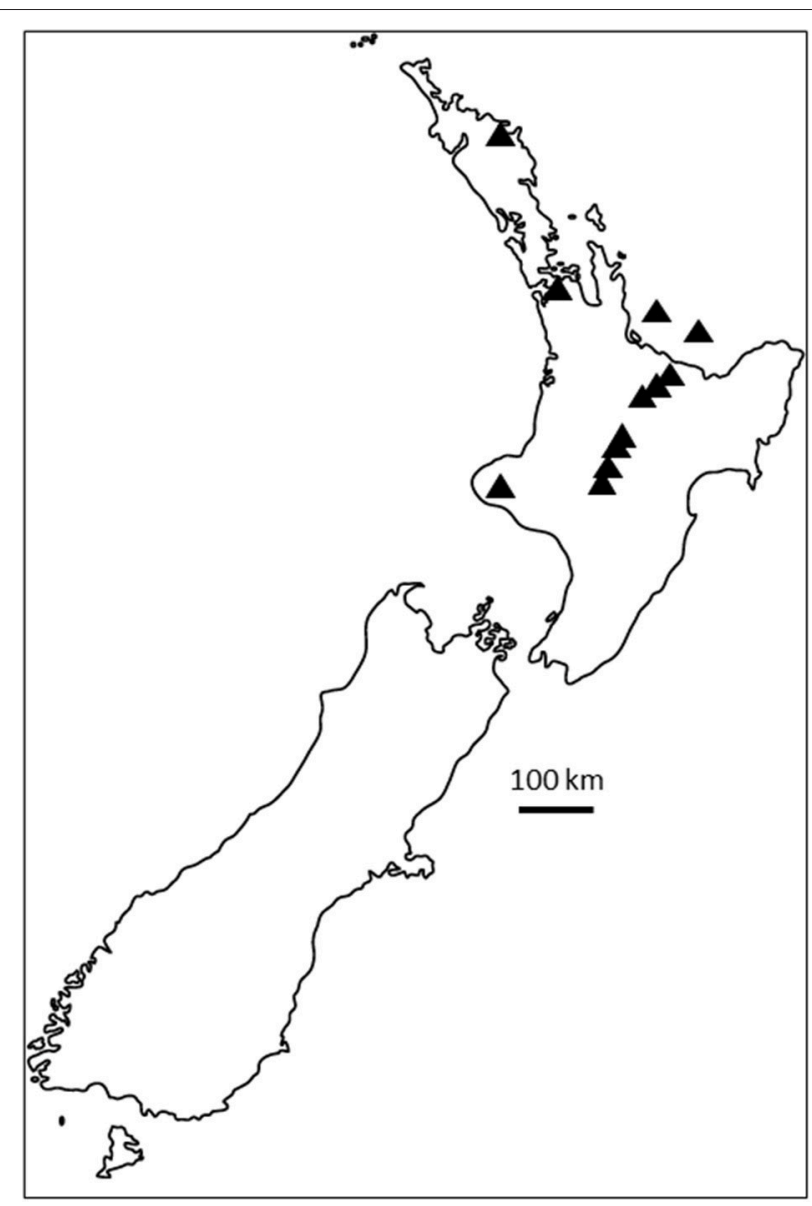

FIGURE 2 | The active volcanic centers of New Zealand (triangles).

bring the volcanic and landslide national probabilistic models up to the standard of the NSHM and NTHM. National coverage, and the ability to provide probabilistic outputs are two main requirements that should be sought for the range of volcanic and landslide hazards.

At a global or regional scale, volcanic hazard modeling efforts have mainly been in the form of generalized assessments (Dilley et al., 2005; Jenkins et al., 2012; Auker et al., 2015; Brown et al., 2015; Miller et al., 2016). These assessments are helpful for enhancing awareness of volcanic hazards, but may not always provide the optimal level of detail to inform decisionmaking by the responsible authorities in specific countries or in specific volcanic regions. The Global Volcano Model (GVM) project was initiated to address such issues at the global scale (Brown et al., 2014; GVM, 2014a,b,c). The GVM mission statement describes the creation of a sustainable, openaccess information platform on worldwide volcanic hazard and risk (globalvolcanomodel.org). Quantification of volcanic hazards and risk would be on global, regional and local (Volcano Observatory) scales. The statement also mentions the development of capabilities to anticipate future volcanism and associated consequences. Our work toward developing a NVHM for New Zealand will greatly benefit from the GVM project as it progresses, and will also be expected to contribute to GVM development in the fullness of time. To date the GVM has produced a series of reports (GVM, 2014a,b,c) on global volcanic hazards and risks as part of the Global Assessment Report on Disaster Risk Reduction (GAR15). As a successor to the Volcano Global Risk Identification and Analysis Project, it is also responsible for the Large Magnitude Explosive Volcanic Eruptions (LaMEVE) worldwide database of 450 Quaternary volcanoes (Crosweller et al., 2012; Brown et al., 2014).

Efforts to characterize volcanic hazard in the USA have largely been on an individual volcano basis, and have resulted in a series of published studies (https://volcanoes.usgs.gov/vhp/hazard_assessments.html).

Considerable efforts to quantify volcanic hazards have also been made in Italy and Indonesia (e.g., Itoh et al., 2000; Alberico et al., 2011). Another internationally-based effort to develop volcanic hazard models is a UK and European collaboration (under the Global Earthquake and Volcanic Eruption Risk Management, or G-EVER consortium; gever.org) to characterize Icelandic volcanic ash production for the purposes of aviation risk assessment. The G-EVER consortium has a "Volcanic Hazard Assessment Support System" (http://volcano.g-ever1.org/vhazard/HazardAssessment/), and a "Next-generation volcanic hazard assessment Working Group" (http://g-ever.org/en/wg/index.html) working on approaches to quantifying volcanic hazard.

For New Zealand to begin the process, in February 2016 a workshop involving volcanologists, statisticians, hazards scientists, and end users was held to scope initial work toward developing a New Zealand National Volcanic Hazard Model (NVHM). The purpose of the meeting was to: (1) solicit input from specialists regarding the development of the NVHM, and; (2) address the data, parameter and methodological needs of the NVHM development through conducting an expert elicitation exercise (Bebbington et al., 2016) following Cooke's classical method (Cooke, 1991). These initiatives are a rejuvenation and elaboration of some earlier efforts (Stirling and Wilson, 2002; Hurst and Smith, 2010), but with more emphasis on multidisciplinary collaboration, consistency of approach, and comprehensive treatment of all volcanic sources. The project also addresses many of the future mitigation strategies defined in the Sendai agreement (http://g-ever.org/en/sendai/index.html).

The following section summarizes our synopsis of the goals that we collectively feel should be addressed in the development of New Zealand's NVHM, and challenges that will face model development.

\section{GOALS OF THE NEW ZEALAND NATIONAL VOLCANIC HAZARD MODEL}

The following describes the goals for the development of the New Zealand NVHM that are based on the recommendations arising from our workshop deliberations, and also draw from the experiences of the NSHM. Though some of the goals are obvious, they are worthwhile summarizing as a record of our 


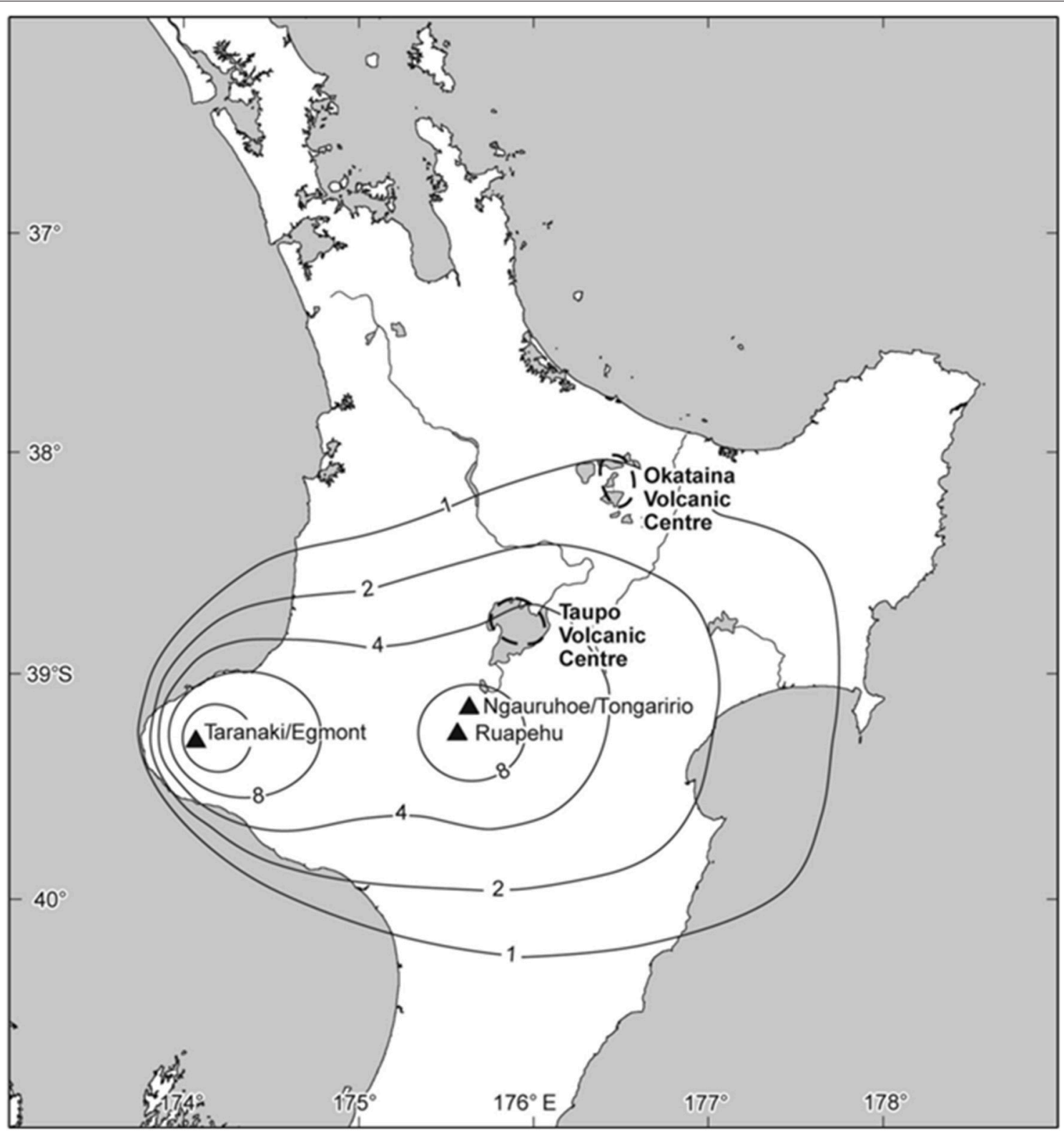

FIGURE 3 | Probabilistic volcanic ashfall hazard map for the North Island. The map shows the ashfall thickness (units of mm) expected with a 10\% probability of exceedance in 50 years (equivalent to a 500 year return period). The source of the map is Hurst and Smith (2010).

deliberations. The goals are briefly listed in Table 1, and then described in more detail in the following text.

1. Recognizing what constitutes sufficient data for achieving a feasible NVHM, and acquiring these data: The most important achievement of a national model should be national coverage. For volcanoes, this means that all actual and realistic volcanic sources should be included in the model, with quantification of the more readily quantifiable volcanic hazards according to the recurrence characteristics of the volcanic sources (eruption magnitude and frequency; e.g., Stirling and Wilson, 2002; Mason et al., 2004), preferably in a time varying model (Bebbington, 2013b). The model needs to include the international volcanic sources likely to impact New Zealand's aviation airspace (e.g., South American volcanoes), and explicitly addressing the diversity of ashfall hazards, from large ashfall events from local sources, to atmospherically transported fine ash from distal sources. In cases such as volcanic fields or complex volcanoes with widely spaced individual source vents, the likely source location would also have to be probabilistically quantified (Bebbington, 2013a). Volcanic ashfall hazard has already been quantified at the national scale (Hurst and Smith, 2010), and these methods provide an important foundation for NVHM development. While the existing ashfall model should be reviewed and updated with any new data and insights that have become 
TABLE 1 | Goals that should be addressed in the development of a NVHM.

1. Identifying and achieving the minimum data requirements for $\mathrm{NVHM}$ development.

2. Gaining the support and acceptance of the NVHM from peers in the scientific and end-user communities.

3. Establishing the NVHM as a versatile open source model.

4. Ability to apply the NVHM to multi-hazard analysis.

5. Ability of the NVHM to directly inform risk assessment.

Each goal is numbered in the same way as they are described in the subsequent text.

available, considerable effort now needs to be focused on quantifying the other volcanic hazards of lahar, pyroclastic density currents, ballistics, debris avalanche, gases/aerosols, and lava flow. At least some of these hazards (eruptive hazards of ashfall and pyroclastic density currents) can be assigned recurrence characteristics that are a function of the overall eruption magnitude and recurrence interval.

The issue of statistical dependence between the various hazards is one that will require considerable attention, given that the many of the volcanic hazards are fundamentally linked within the overall volcanic system. The analogy in seismic hazard modeling is that earthquake motions, fault rupture displacement and liquefaction hazards are all functions of the recurrence behavior of the causative earthquake sources (earthquake magnitude and frequency; Step 2 in Figure 1), as well as physical constraints such as the fault strength and slip type, and the distance from source to site. However, a complexity peculiar to volcanoes is that some of these hazards will also vary in frequency and impact as a consequence of weather conditions (wind direction, presence of rain), local topography, and local hydrology, including the presence or absence of groundwater and snow/ice (e.g., Manville et al., 1998). In addition, large eruptions can be triggered or accompanied by substantial seismic activity (e.g., Abe, 1992; Bebbington and Marzocchi, 2011), so the possibility of earthquake impacts associated with volcanic events needs to be considered.

2. Gaining the support and acceptance of peers in the scientific and end-user communities: Three main considerations are relevant to this challenge. The first is that the scientific credibility of the developers and host organizations of the NVHM need to be high enough to engender widespread confidence. The second is that the model will have to gain a high degree of acceptance throughout the scientific community in order to be considered successful. The third is that the uptake of the model by the end-user communities and decision-making agencies will also need to be widespread before the NVHM development can be considered successful. The model needs to be developed by a team of excellent scientists, hosted by an organization that has demonstrated credibility in volcanic hazard science, and supported by a long-term, reliable government funding pool. An example is GNS Science's 30-plus year stewardship of the NSHM, which has been financially supported by the New Zealand Government for several decades. The scientific credibility of the NVHM would best be achieved by way of interactive workshops which give the scientific community the opportunity to influence model development, along with formal review and publication. These efforts will be aimed at achieving the critical "buy-in" factor. The large number of authors on the most recent NSHM paper (Stirling et al., 2012) is a reflection of the NSHM being developed in a way that was widely supported.

The uptake of the model by end-users is a more complex issue. Clearly, scientific credibility is essential, but key challenges here are to educate the end-users and the broader community on the potential utility of the model, and to ensure that the model meets their needs. This can only be achieved through direct communication with end-user groups. The models need to be understood, and shown to provide useful information. The NSHM has achieved long standing utility in the engineering, planning, and insurance sectors, and has been the hazard basis for two loadings standards, NZS4203 and NZS1170.5 (Standards New Zealand, 1992, 2004). The NTHM has been around for a decade, and has already achieved substantial levels of end-user application. Development of the NTHM was prompted by the occurrence of the 2004 Boxing Day tsunami (Berryman, 2005), and subsequent devastating tsunami events (especially that associated with the $\mathrm{MW}_{W} 9$ 2011 Tohoku earthquake) have continued to emphasize the importance of developing and maintaining the model (Power, 2013). The occurrence of events like the 1995-1996 Ruapehu eruptions, combined with the knowledge of major eruptions in New Zealand's past, have motivated the initial steps toward developing a NVHM over the last 15 years (Stirling and Wilson, 2002; Hurst and Smith, 2010).

The NVHM should ultimately serve those who need to mitigate in a prospective sense (future volcanic hazard), and those who need to react in near-real time (present and immediate future volcanic hazard). The engineering, planning and insurance industries generally require prospective hazard information, whereas the emergency management sector is most concerned with near-real time hazard. Until recently the NSHM was limited to providing long-term future hazard information (Stirling et al., 2012), but the occurrence of the Canterbury earthquake sequence prompted the development of earthquake forecast information in near-real time for the city of Christchurch (Gerstenberger et al., 2014). The analogy is that during times of volcanic unrest the emergency management sector requires eruption forecast information. This information is normally provided by GeoNet (geonet. org.nz), but a NVHM with the ability to develop shortterm (before and during an eruption) forecasts would enhance GeoNet's delivery of relevant and timely information. The various versions of the Bayesian Event Tree software (Marzocchi et al., 2008; Selva et al., 2014; Tonini et al., 2016) also encompass the latter aim.

3. Establishing the NVHM as a versatile open source model: The ability to build, maintain and apply a national hazard model is strongly dependent on the appropriateness of the computer platform and software used to house the model. In this context we can learn from the experiences of NSHM developments in New Zealand and elsewhere. Until recently the NSHM was maintained and used in a Fortran-based computer program that was developed in the 1990s (Stirling et al., 1998), and 
similar software has been used for the USA national maps (e.g., Petersen et al., 2014). Over the years various updates of the computer code and source models have been undertaken, but often in ways that are difficult to track. Nowadays the New Zealand NSHM is in the process of being migrated to the python-based OpenQuake, which is a state-of-the-art software development by the Global Earthquake Model (GEM; Pagani et al., 2014). After around seven years of existence, the GEM project has developed a set of global earthquake source and exposure models that allow global hazard and risk assessments to be carried out (globalquakemodel.org). The software eventually chosen for NVHM development will undoubtedly require periodic upgrades, and this will add cost to maintaining the model. The GEM OpenQuake software is open source, but still requires a team of specialists to maintain the software platform. We do not know what software will be used for the equivalent GVM, but it would ideally be of the same level of sophistication as GEM's OpenQuake. Use of Geographic Information System (GIS) technology would also be useful in storing multiple spatial datasets for the NVHM, and for generating a multitude of hazard outputs according to end-user needs.

4. The ability to use the NVHM in multi-hazard analysis: This is the ability to consider different hazards simultaneously in space and time. At the highest level of natural hazard definition this would involve the simultaneous consideration of volcanic, seismic, tsunami, landslide, and flood hazards. It is difficult to envisage how these hazards could be combined by way of a common hazard metric, so the simultaneous consideration of the hazards would involve modeling them separately, but then combining them in the risk space by way of common loss/impact metrics. The next level down would involve the simultaneous consideration of multiple eruption hazards (e.g., ashfall, ballistics, pyroclastic density current) and consequent hazards that may persist for significant durations after the main eruptive activity (lahar, debris avalanche, gases/aerosols). Lahar and debris avalanche hazards are spatially quantifiable for past events, and able in principle to be linked to a causative volcanic event. The seismic hazard analogy is that seismic shaking, liquefaction, and fault displacement are all measureable in a probabilistic model, and can be simultaneously considered through being produced by the same earthquake event.

5. The ability to directly inform risk assessment: In the last decade hazard analysis has become more strongly linked to risk assessment for seismic and tsunami hazards. The first iteration of the New Zealand NTHM (Berryman, 2005) was developed in parallel with a risk model, and the more recent GEM seismic hazard and risk components have been developed alongside one-another at the global scale. Although we do not expect the development of a national volcanic risk model to happen in parallel with the NVHM development for numerous reasons (e.g., resourcing, maturity of the science of volcanic hazard, and risk assessment), the utility of the NVHM would be greatly enhanced through knowledge of the potential structure and needs of a risk model (e.g., Riskscape.org.nz). Specifically, parallel developments would greatly enhance end-user uptake, and increase the chances of securing support for future model maintenance and updates. Identification of the relevant stakeholders and major asset owners (e.g., utility providers, airlines, agricultural operators, Government agencies), and focusing strongly on their needs during model development, would be an essential part of the process. For instance, a key consideration influencing NVHM development will be the minimum level of spatial aggregation that is applied to risk data/models (e.g., Magill et al., 2006; Zuccaro et al., 2008; Marzocchi et al., 2012; Biass et al., 2013).

There are also goals that may not be able to be pursued as part of initial NVHM development. Operational volcanic forecasting is one such area (e.g., Selva et al., 2012). While real-time monitoring and operational forecasting is a topic of considerable importance in the volcanic hazard domain, and is being actively pursued in other projects, it may be premature to include operational volcanic forecasting in the early development of a NVHM. The proposed NVHM is limited to providing information on the long-term volcanic hazard, but this does not mean that the resulting hazard is time-invariant. If there is dependence between eruptions, particularly at the same volcano, time-dependent information has greater relevance, in a similar way that timedependent models have strong relevance in the Canterbury region for the next few decades (Gerstenberger et al., 2014). The NVHM aims to achieve a sufficient standard and level of completeness of data for New Zealand volcanoes that it can eventually serve as a solid foundation for operational volcanic hazard forecasting. It is vital that the study of volcanic eruption forecasting and predictability should continue to be actively pursued in a parallel research effort. Indeed, the existing ability of GeoNet to provide near-real time information at times of volcanic unrest could both inform and promote the development of forecasting capabilities in the NVHM on an accelerated timescale.

\section{CHALLENGES}

During the workshop we identified a number of challenges that will need to be addressed during the development of the NVHM. These challenges were identified by way of open dialogue among the workshop participants based on collective experience in addressing volcanic hazard, and from the experience of the NSHM and other national models. The challenges that arise in the first instance are those associated with data, hazard measurement metrics, identifying and understanding the potential end-users, developing engineering standards for volcanic hazard, and establishing how the NVHM should be updated over time. The following text provides a list of these challenges, in no specific order of importance, and Table 2 provides more detailed descriptions.

1. Issues of data quality, quantity, and uncertainty in the development of a NVHM: All of the main volcanic centers need to be characterized uniformly in terms of eruption volume and/or mass and associated return period (e.g., Stirling and Wilson, 2002; Hurst and Smith, 2010; Kereszturi et al., 
TABLE 2 | Challenges that will accompany development of a NVHM.

1. Overcoming issues of data quality, quantity and uncertainty.

2. Defining useful source and hazard metrics.

3. Resolving whether different hazards should be combined in the hazard space

or risk space.

4. Identifying and understanding the needs of NVHM end-users.

5. Developing the volcanic equivalent of an earthquake loading standard.

6. Determining how the NVHM should be updated with new data and methods.

7. Defining default volcanic source and hazard models for data-poor volcanic centers.

8. Model validation.

9. Acquiring and maintaining a long-term funding source for NVHM development and maintenance.

Each challenge is numbered in the same way as the more detailed descriptions in the subsequent text.

2013; Green et al., 2016). It is necessary to work in the metrics of volume (dense-rock equivalent of the volume of tephra + lava) and/or mass rather than Volcanic Explosivity Index (VEI; Newhall and Self, 1982) to quantify the physical parameters of the overall eruption. VEI is seen by many as a desirable parameter for its simplicity, completeness, and link to eruption energy release (McNutt, 1994). However, metrics such as magma volume and supply rate (flux), eruption volume or mass, and associated recurrence interval more directly constitute the "engine" (input) of a probabilistic model. The hazards of ashfall and lava flow are functions (albeit complicated and non-linear) of these parameters. Pyroclastic density currents and lahars tend to form the majority of eruption products in the largest events, but are also produced by smaller events.

Individual volcano records have been assembled to varying degrees of completeness and reliability. For example, while the andesitic centers of Taranaki (Alloway et al., 1995; Turner et al., 2011; Damaschke et al., 2016; Green et al., 2016) and Ruapehu (Cronin, 1996; Cronin et al., 1996; Pardo et al., 2012a,b; Scott, 2013) have been described in some detail, large uncertainties still surround the completeness of the associated eruption records. Specifically, the edifice construction histories are still not well constrained for Ruapehu, even though some recent progress has been made (Conway et al., 2016). Information on Ngauruhoe/Tongariro (Topping, 1973; Latter, 1985; Moebis et al., 2011; Scott and Potter, 2014) is even less complete. Other records of note exist for Taupo (Wilson, 1993), Okataina (Jurado-Chichay and Walker, 2000; Nairn, 2002), and the Auckland Volcanic Field (Allen and Smith, 1994; Molloy et al., 2009; Bebbington and Cronin, 2011; Lindsay et al., 2011; Kereszturi et al., 2013; Hopkins et al., 2015; Kawabata et al., 2016), and uncertainties in completeness surround all of these records (e.g., Wang and Bebbington, 2012).

Relationships describing the intensity and areal extent of the hazards also need to be developed from observational data and physical principles. An example is the relationship between topography and lahar volume, extent, and velocity. Considerable uncertainties would also need to be addressed, such as the unknown influence of topographical changes on future eruption dynamics (e.g. lava flows and sector collapses). Numerical approaches (e.g. Titan2D, MAGFLOW, Fall3D, ASHFALL, and TEPHRA2), and statistical approaches (e.g. Rhoades et al., 2002; Kawabata et al., 2013; Kereszturi et al., 2014) are available to address these needs. While ashfall hazard has been quantified numerically as a function of eruption volume, source-to-site distance, and wind direction and frequency for all the major ashfall sources in New Zealand (Hurst and Smith, 2010), no such developments have yet been realized for the other volcanic hazards.

2. Issues with defining useful source and hazard metrics for volcanoes: Eruption location, volume/mass and recurrence interval are fundamental source metrics that are analogous to earthquake location, seismic moment, magnitude, and recurrence interval for seismic sources. Volcanoes, however, have the added complexity that eruptions may stop and start, and total eruption episodes may last for years or more. Furthermore, the eruption episodes may have widely varying hazards and recurrence intervals that do not have equivalently complex analogs in earthquake hazard, except possibly in the context of earthquake swarms and aftershocks. Clearly the most useful hazard metrics will be those that are most appropriate as input to risk assessment (assessment of impact/loss). Ashfall thickness (e.g., Spence et al., 2005) is a hazard metric that is sometimes used as a proxy for loading, and has many correlated impacts, including damage to buildings, contamination of water supplies, and damage to agricultural land (e.g., Wilson et al., 2014). Ashfall can also be characterized in terms of either probability of exceedance, return period, or as a deterministic (scenario) thickness. Lahar hazards (Jenkins et al., 2015), pyroclastic density currents (e.g., Sheridan et al., 2004), and lava flows (e.g., Kereszturi et al., 2014) could be simplistically mapped as paths or footprints that are interpreted from topography, rheology of the mass flow, underlying geology, and historical observations. The return period of these mass flow-related hazards could be based on the eruption recurrence interval and magnitude. Inundation depth and dynamic pressure would then need to be quantified in order to characterize hazard and damage potential. However, there will be difficulties in quantifying the relationship between the hazard return period and the overall eruption volume recurrence interval, areal coverage, and recurrence interval distribution based on an incomplete (biased) geological record.

Further complications arise from uncertain emplacement models that are known to omit critical physical behavioral characteristics of lava, specifically flow inflation. Uncertainties relating to data and model qualities will challenge the whole effort. Furthermore, the overall volume/mass and recurrence interval statistics are inadequate predictors of lahars, pyroclastic density currents, and lava flows. Additional source metrics such as the ratio of effusive to explosive behavior for a given eruption volume, the travel time of the hazard from source to site, and improved physical models are also required. Such metrics and models will need to be developed with heavy reliance on historical analogs and the 
geological record, and then be honed with numerical and analog experimental approaches. We expect these models to carry a greater level of uncertainty than those associated with seismic hazards.

3. The viability, challenges, and benefits of multi-hazard analysis: A long-standing debate is whether hazards should be combined in the hazard space (i.e., multi-hazard modeling) or risk space (i.e., the impact of the hazards as the unifying metric). In the context of volcanic hazard our question is whether the disparate perils of ashfall, lahar, pyroclastic density current, lava flow and others can or should be quantified by a common hazard metric, or whether they can only be given common metrics in the risk space (i.e., loss metrics). A potential unifying hazard metric for at least some of the volcanic hazards could be the force or loading of the hazard, which could scale with destructive potential. Thermal metrics would be another important hazard metric to address. However, destructive potential is a risk-based parameter, and usually quantified through the use of fragility functions. These give the percentage damage and financial loss due to a hazard of a given size, and are developed and applied to disparate structures in risk assessments.

4. The challenges of understanding who the NVHM end-users will be prior to developing the model: Two fundamental requirements from end-users would be, for instance, to quantify the probability of an eruption of a given size in a given time period, and to quantify the size of eruption for a given return period or probability. Models constructed to address longer-term hazard, such as the volcanic equivalent of the 500 year return period seismic hazard maps (the return period of interest for normal engineered structures; e.g., Standards New Zealand, 2004) would be inappropriate for addressing short-term hazard (e.g., months to decades). Strong recommendations or procedures would need to be put in place to ensure such misuse did not happen. GeoNet's potential enduser role could be in requiring the NVHM to assist with the provision of eruption forecast information at times of volcanic unrest, and this would of course require accelerated developments in the relevant model capabilities.

5. Determining the utility and outputs of a volcanic equivalent of the New Zealand Loadings Standard NZS1170.5 (Standards New Zealand, 2004): The Loadings Standard specifies requirements for general structural design and design loadings for buildings (earthquake loadings, and others). It is highly uncertain as to what a volcanic equivalent to the Loadings Standard would look like, and indeed whether it will be required. The definitions of Ultimate Limit State (ULS) and Serviceability Limit State (SLS) motions for earthquakes (Standards New Zealand, 2004) have been very useful for the earthquake engineering profession, as well as the extreme metric of maximum considered earthquake motions. Given that volcanic impacts go beyond disruption to the built environment to such impacts as agriculture and aviation, a volcanic code would clearly be very different to NZS1170.5.

6. The issue of how the NVHM should be updated in the future with new data and methods, especially following a significant eruption: This will be especially important if the functionality of the NVHM is to include short-term hazard. The Canterbury earthquake experience has taught us that updates to data and methods are needed, often with great urgency (e.g., Gerstenberger et al., 2014). Unfortunately however, these updates are also accompanied by concerns about abrupt changes to estimated hazard relative to earlier hazard estimates and loadings standards. Reactive approaches to hazard modeling are often seen as "ambulance chasing," and the elevated awareness inevitably attracts more interest, input, and uncertainty. In the NSHM case, the Canterbury earthquake sequence resulted in considerable interest and input to seismic hazard modeling in New Zealand, with models now being developed in academic and private sectors (e.g., Tarbill et al., 2015). While multiple models always create confusion for end-users, benefits also arise from having more minds on the job at hand, and having to address the key differences between the models (e.g., Stirling and Wesnousky, 1998). All NVHM updates will require the periodic assembly of a large group of experts for specific activities such as planning and review (e.g., the discussions that have led to the preparation of this paper), with smaller groups of experts working on the various model developments.

7. The need to define default volcanic source and hazard models for "data-poor" or "first-time" volcanoes: A relevant New Zealand example is the Northland volcanic field, where very little is known about the ages, eruptive volumes, and recurrence behavior of the volcanic sources. In this setting the volcanoes are considered to be monogenetic (cf. Nemeth and Németh and Kereszturi, 2015).A critically important task that is often given insufficient resources in hazard modeling is that of model validation. This is where the parameter values and outputs are tested and/or evaluated against a variety of criteria. Two examples in seismic hazard analysis are: (i) the evaluation of earthquake forecast models within the Collaboratory for the Study of Earthquake Predictability (CSEP; http://www.cseptesting.org/), and; (ii) the comparison of the predicted ground motions for long return periods to the fragility of ancient precariously-balanced rocks (e.g., Stirling and Anooshehpoor, 2006). A potential example of testing and evaluation of volcanic hazard models could be whether or not the actual ashfall loading at multiple sites is within the forecast limits at those sites (although consideration must be taken of subsequent erosion and bioturbation). A testing and evaluation framework will need to be established for the NVHM, which will require careful conceptualization to deal with validation in time, space and hazard-type, and will need to pay attention to issues like circularity (data used in the model also used in validation).

8. Funding the NVHM: The development, maintenance, and periodic update of the NVHM with new data and reinterpretation of the database based on the current stateof-the-art thinking of experts will require considerable human resources and a commitment to long-term funding. Experience with the NSHM has shown that stable funding is required to grow and maintain national capability. This ensures that national models are developed and stay current 
with respect to advances in data, results and methods. The development of the NVHM will be very difficult unless a long-term funded program is put in place and carefully managed. The extensive and ongoing tasks associated with model development and update will require focused efforts and ongoing financial support. In reality, funding will need to be allocated according to a logical prioritization strategy. Parameters such as human and property risk exposure, public concern, and political interest/importance would feature in such a strategy.

\section{DISCUSSION}

We have outlined the range of goals and challenges associated with the development of a New Zealand NVHM. Development of the NVHM will require a sufficient and reliable source of funding, and a durable, and reputable host institution that houses much of the core expertise, datasets, and computing power relevant to volcanic hazard modeling and forecasting. Development and subsequent update of the NVHM will need to occur by way of standardized procedures and protocols.

The first large task of building the NVHM will be the development of source models in the form of a catalog that includes eruption volume and recurrence interval for every volcanic center in the country, as well as for international centers that are likely to impact New Zealand (e.g., South American volcanoes). We will need to compile existing published data, determine the best way to characterize the volume and return period of volcanic eruptions, and define the time period over which the volcanic records need to be established. Two key issues will be: distinguishing the actual lower limits of eruption volume from the smallest eruptions in an incomplete eruption record, and constraining the recurrence model for eruption volumes. The simplest approach for the latter would be to assume each eruption arrives randomly and independently (e.g., Jenkins et al., 2012; Bear-Crozier et al., 2016), although this may not be the most appropriate approach. Another might be to apply conditional methods, such as quantifying the distribution of time to the next eruption onset, or the location of the next vent (e.g., Marzocchi and Bebbington, 2012; Bebbington, 2015). We note that at present very few methods forecast the size of a future event (e.g., Marzocchi and Zaccarelli, 2006; Bebbington, 2014), and this could be an important developmental area for the NVHM in the domain of forecasting. Volcanoes like Taupo show complex relationships between eruption volume and repose periods before or after events (Wilson, 1993), and require the application of probabilistic methods.

The second task will be to revise the national ashfall hazard model (Hurst and Smith, 2010). At present, final ashfall thickness is the most readily modeled metric that can be used to quantify volcanic hazard. Although a simplistic parameter in the context of damage (a measure of ashfall loading would be an additional useful parameter), ashfall hazard will be directly linked to the source model (eruption volume and recurrence interval à ashfall thickness and likelihood), using relationships describing ash thickness as a function of source, distance, wind direction/frequency, and eruption column height (acknowledging uncertainties in ashfall density due to factors such as rainfall at time of eruption). However, many volcanic centers are not characterized to any levels of completeness, and well-established relationships relating volcanic eruption volume to the severity of these hazards (thickness, areal extent) do not exist. Heavy reliance on the use of simplistic assumptions will be needed at least initially. For instance, in the absence of better models, the mapped or assumed paths of lahars, pyroclastic density currents, and lava flows could be simplistically assumed to be active with a probability derived from the ashfall volume (a monotonic function, possibly with some critical value). More sophisticated approaches could be in the application of physical models (if available), and predictive relationships for the range of hazards could be arrived at through the use of event trees (Newhall and Hoblitt, 2002; Selva et al., 2010) and application of expert elicitation methods (Cooke, 1991).

Throughout these tasks of NVHM development the developers will need to be in close contact with the relevant stakeholders to ensure that their needs will be appropriately addressed by the NVHM. Formation of steering groups, and hosting of stakeholder workshops will ensure the NVHM is developed in such a way that stakeholders are informed and can have vital input as to model purpose, utility and direction.

We consequently identify the following research topics that we feel should be supported in the context of NVHM development:

1. Conduct an extensive review of national and international volcanic hazard modeling efforts, to ascertain whether any existing approaches have been applied, and others that can potentially be applied or adapted to the New Zealand NVHM.

2. Solicit feedback from potential end-users of a NVHM, and instruct them on the appropriate use and limitations of the NVHM.

3. Develop a national eruption source model, in which each source is assigned an eruption volume (and/or mass)-return period relationship (e.g., Latter, 1985; Stirling and Wilson, 2002) and, where necessary, sources are spatially quantified.

4. Develop new models for the emplacement of lavas across areas of low topography, given that no such models currently exist for New Zealand or elsewhere.

5. Develop and agree on a model for emplacement of pyroclastic density currents, acknowledging that there is an enormous range of phenomena and consequent hazards encompassed by these phenomena.

6. Generate, review and revise existing probabilistic volcanic ashfall forecasting relationships, and apply these to all relevant volcanic sources.

7. Develop an updated ashfall NVHM for New Zealand, using the results of points 3 and 4, above.

8. Map the actual and potential (modeled) distribution of lahars, pyroclastic density currents, lava flows, ballistics, debris avalanche, and gases/aerosols using historical and geological observations, remote sensing datasets, topographical and geodetic data for all potentially active volcanic centers, and meteorological data/models. At least 
some of these features have already been mapped on the major volcanic centers where topographic control is clearly definable, and volcanic activity tends to be within a relatively narrow size-range (e.g., Ruapehu and Taranaki).

9. Seek to forecast the component of an eruption volume that goes into the hazards listed above. In addition, the important input parameters of eruption style and volume rate has to be identified and included in the model, as these partition the volume according to type and time. Consideration of these aspects in the context of overall eruption classification is currently a topic of active debate (Bonadonna et al., 2016; Houghton et al., 2016). We anticipate that different relationships will have to be developed for the different volcanic centers. The particular hazard and associated severity may depend on the exact siting of the vent position within the volcano structure (e.g., contrasting styles of rhyolite volcanism depending on whether or not the vent encounters bodies of external water; Houghton et al., 2003).

10. Develop separate NVHMs for the hazards listed above. The results should be integrated in a GIS platform that is able to analyse spatial data using multi-layered data structure. This platform has a great potential to explore and develop the spatial and temporal distribution of volcanic hazard.

11. Investigate the potential utility of the volcanic hazard equivalent of an engineering standard that includes all potential impacts (e.g., for the agricultural, forestry, environmental, and aviation sectors).

12. Development of an appropriate policy for maintenance and update of the NVHM, especially for enhanced support for when a significant volcanic event takes place.

13. Further research to understand and quantify fault ruptureeruption relationships.

The above represents a formidable list of research activities that will span multiple years, and this effort need to be founded on a stable infrastructure. This means a sound basis for the working NVHM, longevity of the host institution, and

\section{REFERENCES}

Abe, K. (1992). Seismicity of the caldera-making eruption of Mount Katmai, Alaska in 1912. Bull. Seismol. Soc. Am. 82, 175-191.

Alberico, I., Petrosino, P., and Lirer, L. (2011). Volcanic hazard and risk assessment in a multisource volcanic area, the example of Napoli city (Southern Italy). Nat. Hazard Earth Syst. Sci. 11, 1057-1070. doi: 10.5194/nhess-11-10 57-2011

Allen, S. R., and Smith, I. E. M. (1994). Eruption styles and volcanic hazard in the Auckland volcanic field, New Zealand. Geosci. Rep. Shizuoka Univ. 20, $5-14$.

Alloway, B. V., Neall, V. E., and Vucetich, C. G. (1995). Late quaternary (post 28,000 year B.P.) tephrostratigraphy of northeast and central Taranaki, New Zealand. J. R. Soc. N. Z. 25, 385-458. doi: 10.1080/03014223.1995. 9517496

Auker, M. R., Sparks, R. S. J., Jenkins, S. F., Aspinall, W., Brown, S. K., Deligne, N. I., et al. (2015). "Development of a new global volcanic hazard index (VHI)," in Global Volcanic Hazards and Risk, eds S. Loughlin, R. S. J. Sparks, S. Brown, S. Jenkins, and C. Vye-Brown (Cambridge: Cambridge University Press), 349-358. long-term commitment from the host institution and funding agencies).

\section{SUMMARY AND CONCLUSIONS}

We have provided a synthesis of a workshop held in early 2016 to define the goals, challenges and first steps associated with developing a national probabilistic volcanic hazard model for New Zealand. The development of a national volcanic hazard model is a formidable task that will require long-term stability in terms of team effort, collaboration and funding, as well as novel means of dealing with the great variety of hazards and risks posed by volcanoes. The model will need to be developed in stages or editions that incorporate successive hazards over time. The first edition is likely to be limited to an update of the Hurst and Smith (2010) ashfall hazard model, with other volcanic hazards being considered in subsequent updates.

\section{AUTHOR CONTRIBUTIONS}

MS led the manuscript preparation, submission, and revision. MS and MBe coordinated the research. $\mathrm{MBr}, \mathrm{SC}, \mathrm{AC}, \mathrm{ND}, \mathrm{TH}$, AJ, GJ, BK, GK, JL, VN, JP, DR, BS, PS, IS, RS, TWi, JW, CW, and TWa took part in the workshops, and provided inputs to the manuscript preparation and revision.

\section{ACKNOWLEDGMENTS}

This work has been supported by the Natural Hazards Research Platform funded by the New Zealand Ministry for Business Innovation and Employment, and by the following host institutions of the workshop participants: University of Otago, Massey University, GNS Science, Victoria University of Wellington, University of Auckland, University of Canterbury, and the Earthquake Commission.

Bear-Crozier, A. N., Miller, V., Newey, V., Horspool, N., and Weber, R. (2016). Probabilistic volcanic ash hazard analysis (PVAHA) I: development of the VAPAH tool for emulating multi-scale volcanic ash fall analysis. J. Appl. Volcanol. 5:3. doi: 10.1186/s13617-0160043-4

Bebbington, M., and Cronin, S. J. (2011). Spatio-temporal hazard estimation in the Auckland volcanic field, New Zealand, with a new eventorder model. Bull. Volcanol. 73, 55-72. doi: 10.1007/s00445-0100403-6

Bebbington, M. S. (2013a). Assessing spatio-temporal eruption forecasts in a monogenetic volcanic field. J. Volcanol. Geotherm. Res. 252, 14-28. doi: 10.1016/j.jvolgeores.2012. 11.010

Bebbington, M. S. (2013b). Models for temporal volcanic hazard. Stat. Volcanol. 1, 1-24. doi: 10.5038/2163-338x.1.1

Bebbington, M. S. (2014). Long-term forecasting of volcanic explosivity. Geophys. J. Int. 197, 1500-1515. doi: 10.1093/gji/ggu078

Bebbington, M. S. (2015). "Volcanic eruptions: stochastic models of occurrence patterns," in Encyclopedia of Complexity and System Science, 2nd Edn, ed R. A. Meyers (New York, NY: Springer), 1-58. 
Bebbington, M. S., and Marzocchi, W. (2011). Stochastic models for earthquake triggering of volcanic eruptions. J. Geophys. Res. 116:B05204. doi: 10.1029/2010JB008114

Bebbington, M., Stirling, M., Cronin, S., Wang, T., and Jolly, G. (2016). First Steps to a National Volcano Hazard Model: Estimation of Time Varying Hazard from New Zealand Volcanoes through Expert Elicitation and Bayesian Analogues. Preliminary Report, Natural Hazards Research Platform.

Berryman, K. R. (2005). Review of Tsunami Hazard in New Zealand. GNS Science Client Report 2005/104, Institute of Geological and Nuclear Sciences, Lower Hutt.

Biass, S., Frischknecht, C., and Bonadonna, C. (2013). A fast GIS-based risk assessment for tephra fallout: the example of Cotopaxi volcano, Ecuador. Part II: vulnerability and risk assessment. Nat. Hazards 65, 497-521. doi: 10.1007/s11069-012-0457-1

Bonadonna, C., Cioni, R., Costa, A., Druitt, T., Phillips, J., Pioli, L., et al. (2016). MeMoVolc report on classification and dynamics of volcanic explosive eruptions. Bull. Volcanol. 78:84. doi: 10.1007/s00445-0161071-y

Brown, S. K., Crosweller, H. S., Sparks, R. S. J., Cottrell, E., Deligne, N. I., Guerrero, N. O., et al. (2014). Characterisation of the quaternary eruption record: analysis of the large magnitude explosive eruptions (LaMEVE) database. J. Appl. Volcanol. 3:5. doi: 10.1186/2191-5040-3-5

Brown, S. K., Loughlin, S. C., Sparks, R. S. J., Vye-Brown, C., Barclay, J., Calder, E., et al. (2015). "Global volcanic hazard and risk," in Global Volcanic Hazards and Risk, eds S. Loughlin, R. S. J. Sparks, S. Brown, S. Jenkins, and C. Vye-Brown (Cambridge: Cambridge University Press), 81-172.

Conway, C. E., Leonard, G. S., Townsend, D. B., Calvert, A. T., Wilson, C. J. N., Gamble, J. A., et al. (2016). A high-resolution $40 \mathrm{Ar} / 39 \mathrm{Ar}$ lava chronology and edifice construction history for Ruapehu volcano, New Zealand. J. Volcanol. Geotherm. Res. 327, 152-179. doi: 10.1016/j.jvolgeores.2016. 07.006

Cooke, R. M. (1991). Experts in Uncertainty: Opinion and Subjective Probability in Science. New York, NY: Oxford Univ Press, 336.

Cornell, C. A. (1968). Engineering seismic risk analysis, Bull. Seismol. Soc. Am. 58, 1583-1606.

Cronin, S. J. (1996). Late Quaternary Volcanic Stratigraphy within a Portion of the Northeastern Tongariro Volcanic Centre. Unpublished Ph. D. thesis, Massey University, Palmerston North.

Cronin, S. J., Neall, V. E., Stewart, R. B., and Palmer, A. S. (1996). A multiple-parameter approach to andesitic tephra correlation, Ruapehu volcano, New Zealand. J. Volcanol. Geotherm. Res. 72, 199-215. doi: 10.1016/0377-0273(96)00008-X

Crosweller, H. S., Aroa, B., Brown, S. K., Cottrell, E., Deligne, N. I., Guerrero, N. O., et al. (2012). Global database on large magnitude explosive volcanic eruptions (LaMEVE). J. Appl. Volcanol. 1:4. doi: 10.1186/2191-5040-1-4

Damaschke, M., Cronin, S. J., Holt, K. A., Bebbington, M. S., and Hogg, A. (2016). A new 30,000 year high precision eruption history for the andesitic Mt Taranaki, North Island, New Zealand. Quatern. Res. 87, 1-23. doi: 10.1017/qua.2016.11

Dellow, G. D., Buxton, R., Joyce, K. E., and Matcham, I. R. (2013). A probabilistic rainfall-induced landslide hazard model for New Zealand. Eng. Geol. 182, 3-14.

Dilley, M., Chen, R. S., Deichmann, U., Lerner-Lam, A. L., and Arnold, M. (2005). Natural Disaster Hotspots: a Global Risk Analysis. Washington, DC: World Bank.

Gerstenberger, M. C., McVerry, G. H., Rhoades, D. A., and Stirling, M. W. (2014). Seismic hazard modelling for the recovery of Christchurch, New Zealand. Earthquake Spectra 30, 17-29. doi: 10.1193/021913EQS037M

Green, R. M., Bebbington, M. S., Jones, G., Cronin, S. J., and Turner, M. B. (2016). Estimation of tephra volumes from sparse and incompletely observed deposit thicknesses. Bull. Volcanol. 78:25. doi: 10.1007/s00445-0161016-5

Global Volcano Model (2014a). Global Volcanic Hazards and Risk. Summary Paper. Background Paper Prepared for the 2015 global assessment report on disaster risk reduction, UNISDR, Geneva.

Global Volcano Model (2014b). Global Volcanic Hazards and Risk. Technical background paper prepared for the 2015 global assessment report on disaster risk reduction, UNISDR, Geneva.
Global Volcano Model (2014c). Global Distribution of Volcanism: Regional and Country Profiles. Report Prepared for the 2015 global assessment report on disaster risk reduction, UNISDR, Geneva.

Hopkins, J. L., Millet, M., Timm, C., Wilson, C. J. N., Leonard, G. S., Palin, J. M., et al. (2015). Tools and techniques for developing tephra stratigraphies in lake cores: a case study from the basaltic Auckland volcanic field, New Zealand. Quat. Sci. Rev. 123, 58-75. doi: 10.1016/j.quascirev.2015. 06.014

Houghton, B. F., Swanson, D. A., Rausch, R. J., Carey, S. A., and Fagents, T. R. (2016). Pushing the volcanic explosivity index to its limit and beyond: constraints from exceptionally weak explosive eruptions at Kilauea in 2008. Geology 41, 627-630. doi: 10.1130/ G34146.1

Houghton, B. F., Hobden, B. J., Cashman, K. V., Wilson, C. J. N., and Smith, R. T. (2003). Large-scale interaction of lake water and rhyolitic magma during the 1.8 ka Taupo eruption, New Zealand. Am. Geophys. Union Geophys. Monogr. 140, 97-109. doi: 10.1029/140gm06

Hurst,. T., and Smith, W. (2010). Volcanic ashfall in New Zealand - probabilistic hazard modelling for multiple sources. N. Z. J. Geol. Geophys. 53, 1-14. doi: 10.1080/00288301003631129

IAEA (2012). Volcanic Hazards in Site Evaluation for Nuclear Installations. IAEA Safety Standards Series SSG-21, IAEA, Vienna.

IAEA (2016). Volcanic Hazard Assessments for Nuclear Installations: Methods and Examples in Site Evaluation. IAEA-TecDoc-1795, IAEA, Vienna.

Itoh, H., Takahama, J., Takahashi, M., and Miyamoto, K. (2000). Hazard estimation of the possible pyroclastic flow disasters using numerical simulation related to the 1994 activity at Merapi Volcano. J. Volcanol. Geotherm. Res. 100, 503-516. doi: 10.1016/S0377-0273(00)00153-0

Jenkins, S., Magill, C., McAneney, J., and Blong, R. (2012). Regional ash fall hazard I: a probabilistic assessment methodology. Bull. Volcanol. 74, 1699-1712. doi: 10.1007/s00445-012-0627-8

Jenkins, S., Phillips, J., Price, R., Feloy, K., Baxter, P. J., Hadmoko, D. S., et al. (2015). Developing building-damage scales for lahars: application to Merapi volcano, Indonesia. Bull. Volcanol. 77:75. doi: 10.1007/s00445-015-0961-8

Jurado-Chichay, Z., and Walker, G. P. L. (2000). Stratigraphy and dispersal of the mangaone subgroup pyroclastic deposits, Okataina Volcanic Centre, New Zealand. J. Volcanol. Geotherm. Res. 104, 319-383. doi: 10.1016/S0377-0273(00)00210-9

Kawabata, E., Bebbington, M. S., Cronin, S. J., and Wang, T. (2013). Modeling thickness variability in tephra deposition. Bull. Volcanol. 75:738. doi: 10.1007/s00445-013-0738-x

Kawabata, E., Bebbington, M. S., Cronin, S. J., and Wang, T. (2016). Optimal likelihood matching of volcanic sources and deposits in the Auckland volcanic field. J. Volcanol. Geotherm. Res. 323, 194-208. doi: 10.1016/j.jvolgeores.2016.05.004

Kereszturi, G., Cappello, A., Ganci, G., Procter, J., Németh, K., Del Negro, C., et al. (2014). Numerical simulation of basaltic lava flows in the Auckland volcanic field, New Zealand-implication for volcanic hazard assessment. Bull. Volcanol. 76:879. doi: 10.1007/s00445-0140879-6

Kereszturi, G., Németh, K., Cronin, S. J., Agustín-Flores, J., Smith, I. E. M., and Lindsay, J. (2013). A model for calculating eruptive volumes for monogenetic volcanoes-Implication for the Quaternary Auckland volcanic field, New Zealand. J. Volcanol. Geotherm. Res. 266, 16-33. doi: 10.1016/j.jvolgeores.2013.09.003

Latter, J. H. (1985). Frequency of eruptions at New Zealand volcanoes. Bull. N. Z. Soc. Earthquake Eng. 18, 55-101.

Lindsay, J. M., Leonard, G. S., Smid, E. R., and Hayward, B. W. (2011). Age of the Auckland volcanic field: a review of existing data. N.Z. J. Geol. Geophys. 54, 379-401. doi: 10.1080/00288306.2011. 595805

Magill, C., Blong, R., and McAneney, J. (2006). VolcaNZ - a volcanic loss model for Auckland, New Zealand. J. Volcanol. Geotherm. Res. 149, 329-345. doi: 10.1016/j.jvolgeores.2005.09.004

Manville, V., Hodgson, K. A., and White, J. D. L. (1998). Rheological properties of a remobilised-tephra lahar associated with the 1995 eruptions of Ruapehu volcano, New Zealand. 
N.Z. J. Geol. Geophys. 41, 157-164. doi: 10.1080/00288306.1998. 9514800

Marzocchi, W., and Bebbington, M. (2012). Probabilistic eruption forecasting at short and long time scales. Bull. Volcanol. 74, 1777-1805. doi: $10.1007 / \mathrm{s} 00445-012-0633-\mathrm{x}$

Marzocchi, W., Garcia-Aristizabal, A., Gasparini, P., Mastellone, M. L., and Di Ruocco, A. (2012). Basic principles of multi-risk assessment: a case study in Italy. Nat. Hazards 62, 551-573. doi: 10.1007/s11069-012-0092-x

Marzocchi, W., Sandri, L., and Selva, J. (2008). BET_EF: a probabilistic tool for long- and short-term eruption forecasting. Bull. Volcanol. 70, 623-632. doi: 10.1007/s00445-007-0157-y

Marzocchi, W., and Zaccarelli, L. (2006). A quantitative model for the time-size distribution of eruptions. J. Geophys. Res. 111:B04204. doi: $10.1029 / 2005$ jb003709

Mason, B. G., Pyle, D. M., and Oppenheimer, C. (2004). The size and frequency of the largest explosive eruptions on Earth. Bull. Volcanol. 66, 735-748. doi: $10.1007 / \mathrm{s} 00445-004-0355-9$

McNutt, S. R. (1994). Volcanic tremor amplitude correlated with eruption explosivity and its potential use in determining ash hazards to aviation. U.S. Geol. Survey Bull. 2047, 377-385.

Miller, V., Bear-Crozier, A. N., Newey, V., Horspool, N., and Webere, R. (2016). Probabilistic volcanic ash analysis (PVAHA) II: assessment of the Asia-Pacific region using VAPAH. J. Appl. Volcanol. 5:4. doi: 10.1186/s13617-016-0044-3

Moebis, A., Cronin, S. J., Neall, V. E., and Smith, I. E. (2011). Unravelling a complex volcanic history from fine-grained, intricate Holocene ash sequences at the Tongariro volcanic centre, New Zealand. Quat. Int. 246, 352-363. doi: 10.1016/j.quaint.2011.05.035

Molloy, C., Shane, P., and Augustinus, P. (2009). Eruption recurrence rates in a basaltic volcanic field based on tephra layers in maar sediments: implications for hazards in the Auckland volcanic field. Geol. Soc. Am. Bull. 121, 1666-1677. doi: 10.1130/B26447.1

Nairn, I. A. (2002). Geology of the Okataina Volcanic Centre, Scale 1:50,000. Institute of Geological \& Nuclear Sciences Geological Map 25. Lower Hutt: Institute of Geological \& Nuclear Sciences Limited.

Németh, K., and Kereszturi, G. (2015). Monogenetic volcanism: personal views and discussion. Int. J. Earth Sci. 104, 2131-2146. doi: 10.1007/s00531-0151243-6

Newhall, C. G., and Hoblitt, R. P. (2002). Constructing event trees for volcanic crises. Bull. Volcanol. 64, 3-20. doi: 10.1007/s004450100173

Newhall, C. G., and Self, S. (1982). The volcanic explosivity index (VEI): an estimate of the explosive magnitude for historical eruptions. J. Geophys. Res. 87, 1231-1238. doi: 10.1029/JC087iC02p01231

Pagani, M., Monelli, D., Weatherill, G., and Vigano, D. (2014). OpenQuake engine: an open hazard (and risk) software for the global earthquake model. Seismol. Res. Lett. 85, 692-702. doi: 10.1785/0220130087

Pardo, N., Cronin, S. J., Palmer, A. S., and Nemeth, K. (2012a). Reconstructing the largest explosive eruptions of Mt. Ruapehu, New Zealand: lithostratigraphic tools to understand subplinian-plinian eruptions at andesitic volcanoes. Bull. Volcanol. 74, 617-640. doi: 10.1007/s00445-0110555-Z

Pardo, N., Cronin, S., Palmer, A., Proctor, J., and Smith, I. (2012b). Andesitic Plinian eruptions at Mt Ruapehu: quantifying the uppermost limits of eruptive parameters. Bull. Volcanol. 74, 1161-1185. doi: 10.1007/s00445-0120588-y

Petersen, M., Moschetti, M., Powers, P., Mueller, C., Haller, K., Frankel, A., et al. (2014). Documentation for the 2014 Update of the United States National Seismic Hazard Maps. Open File Report 2014-1091, U.S. Geological Survey.

Power, W. (2013). Review of Tsunami Hazard in New Zealand. GNS Science Consultancy Report 2013/131. Institute of Geological and Nuclear Sciences, Lower Hutt.

Reiter, L. (1990). Earthquake Hazard Analysis. New York, NY: Columbia University Press, 254.

Rhoades, D. A., Dowrick, D. J., and Wilson, C. J. N. (2002). Volcanic hazard in New Zealand: scaling and attenuation relations for tephra fall deposits from Taupo Volcano. Nat. Hazards 26, 147-174. doi: 10.1023/A:10156087 32356

Scott, B. J. (2013). A Revised Catalogue of Ruapehu Volcano Eruptive Activity: 1830-2012. GNS Science report 2013/45, GNS Science, Lower Hutt, 107.
Scott, B. J., and Potter, S. H. (2014). Aspects of historical eruptive activity and volcanic unrest at Mt Tongariro, New Zealand: 1846-2013. J. Volcanol. Geotherm. Res. 286, 263-276. doi: 10.1016/j.jvolgeores.2014. 04.003

Selva, J., Costa, A., Marzocchi, W., and Sandri, L. (2010). BET_VH: exploring the influence of natural uncertainties on long-term hazard from tephra fallout at Campi Flegrei (Italy). Bull. Volcanol. 72, 717-733. doi: 10.1007/s00445-010-0358-7

Selva, J., Costa, A., Sandri, L., Macedonio, G., and Marzocchi, W. (2014). Probabilistic short-term volcanic hazard in phases of unrest: a case study for tephra fallout. J. Geophys. Res. 119, 8805-8826. doi: 10.1002/2014jb011252

Selva, J., Marzocchi, W., Papale, P., and Sandri, L. (2012). Operational eruption forecasting at high-risk volcanoes: The case of Campi Flegrei, Naples. J. Appl. Volcanol. 1:5. doi: 10.1186/2191-5040-1-5

Sheridan, M. F., Hubbard, B., Carrasco-Nú-ez, G., and Siebe, C. (2004). Pyroclastic flow hazard at Volcán Citlaltépetl. Nat. Hazards 33, 209-221. doi: 10.1023/B:NHAZ.0000037028.89829.d1

Smith, W. D., and Berryman, K. R. (1986). "Earthquake hazard in New Zealand: inferences from seismology and geology," in Recent Crustal Movements of the Pacific Region, Vol. 24, eds W. I. Reilly and B. E. Harford (Wellington: Bulletin Royal Society), 223-243.

Spence, R. J. S., Kelman, I., Baxter, P. J., Zuccaro, G., and Petrazzuoli, S. (2005). Residential building and occupant vulnerability to tephra fall. Nat. Hazards Earth Syst. Sci. 5, 477-494. doi: 10.5194/nhess-5-477-2005

Stirling, M. W., and Anooshehpoor, R. (2006). Constraints on probabilistic seismic-hazard models from unstable landform features in New Zealand. Bull. Seismol. Soc. Am. 96, 404-414. doi: 10.1785/0120050034

Stirling, M. W., McVerry, G. H., and Berryman, K. R. (2002). A new seismic hazard model for New Zealand. Bull. Seismol. Soc. Am. 92, 1878-1903. doi: $10.1785 / 0120010156$

Stirling, M. W., McVerry, G. H., Gerstenberger, M. C., Litchfield, N. J., Van Dissen, R. J., Berryman, K. R., et al. (2012). National seismic hazard model for New Zealand: 2010 update. Bull. Seismol. Soc. Am. 102, 1514-1542. doi: $10.1785 / 0120110170$

Stirling, M. W., and Wesnousky, S. G. (1998). Comparison of recent probabilistic seismic hazard maps for southern California. Bull. Seismol. Soc. Am. 88, 855-861.

Stirling, M. W., Wesnousky, S. G., and Berryman, K. R. (1998). Probabilistic seismic hazard analysis of New Zealand. N. Z. J. Geol. Geophys. 41, 355-375. doi: 10.1080/00288306.1998.9514816

Stirling, M. W., and Wilson, C. J. N. (2002). Development of a volcanic hazard model for New Zealand: first approaches from the methods of probabilistic seismic hazard analysis. Bull. N. Z. Soc. Earthquake Eng. 35, 266-277. Available online at: http://www.nzsee.org.nz/db/Bulletin/Archive/35(4)0266.pdf

Standards New Zealand (1992). NZS 4203:1992 Volumes 1 and 2: General Structural Design and Design Loadings for Buildings. Wellington: Dept. Building and Housing.

Standards New Zealand (2004). Structural Design Actions-Part 5: Earthquake Actions-New Zealand, New Zealand Standard NZS 1170.5. Wellington: Dept. Building and Housing.

Tarbill, K., Bradley, B., and Cubrinovski, M. (2015). "Nationwide seismic hazard maps of New Zealand using recent developments in rupture forecast and ground motion prediction," in Proceedings of the New Zealand Society of Earthquake Engineering Annual Conference, 2015, Christchurch.

Tonini, R., Sandri, L., Rouwet, D., Caudron, C., Marzocchi, W., and Suparjan (2016). A new Bayesian event tree tool to track and quantify volcanic unrest and its application to Kawah Ijen volcano. Geochem. Geophys. Geosyst. 17, 2539-2555 doi: 10.1002/2016GC006327

Topping, W. W. (1973). Tephrostratigraphy and chronology of late Quaternary eruptives from Tongariro volcanic centre, New Zealand. N. Z. J. Geol. Geophys. 16, 397-423. doi: 10.1080/00288306.1973.10431368

Turner, M. B., Cronin, S. J., Bebbington, M. S., Smith, I. E. M., and Stewart, R. B. (2011). Integrating records of explosive and effusive activity from proximal and distal sequences: Mt. Taranaki, New Zealand. Quat. Int. 246, 364-373. doi: 10.1016/j.quaint.2011.07.006

Wang, T., and Bebbington, M. (2012). Estimating the likelihood of an eruption from a volcano with missing onsets in its record. J. Volcanol. Geotherm. Res. 243-244, 14-23. doi: 10.1016/j.jvolgeores.2012.06.032 
Wilson, C. J. N. (1993). Stratigraphy, chronology, styles and dynamics of late Quaternary eruptions from Taupo Volcano, New Zealand. Philos. Trans. R. Soc. Lond. A 343, 205-306. doi: 10.1098/rsta.1993. 0050

Wilson, G., Wilson, T. M., Deligne, N. I., and Cole, J. W. (2014), Volcanic hazard impacts to critical infrastructure: a review. J. Volcanol. Geotherm. Res. 286, 148-182. doi: 10.1016/j.jvolgeores.2014. 08.030

Zuccaro, G., Cacace, F., Spence, R. J. S., and Baxter, P. J. (2008). Impact of explosive eruption scenarios at Vesuvius. J. Volcanol. Geotherm. Res. 178, 416-453. doi: 10.1016/j.jvolgeores.2008. 01.005
Conflict of Interest Statement: The authors declare that the research was conducted in the absence of any commercial or financial relationships that could be construed as a potential conflict of interest.

Copyright (๑) 2017 Stirling, Bebbington, Brenna, Cronin, Christophersen, Deligne, Hurst, Jolly, Jolly, Kennedy, Kereszturi, Lindsay, Neall, Procter, Rhoades, Scott, Shane, Smith, Smith, Wang, White, Wilson and Wilson. This is an open-access article distributed under the terms of the Creative Commons Attribution License (CC BY). The use, distribution or reproduction in other forums is permitted, provided the original author(s) or licensor are credited and that the original publication in this journal is cited, in accordance with accepted academic practice. No use, distribution or reproduction is permitted which does not comply with these terms. 